\title{
Project Management Body of Knowledge for motion picture production in a fast-developing economy
}

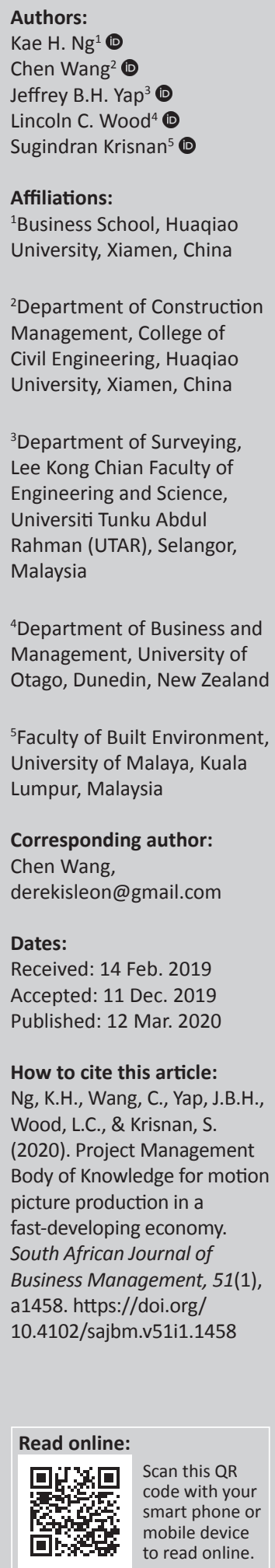

${ }^{4}$ Department of Business and Management, University of Otago, Dunedin, New Zealand

${ }^{5}$ Faculty of Built Environment, University of Malaya, Kuala Lumpur, Malaysia

Corresponding author: Chen Wang,

derekisleon@gmail.com

Dates:

Received: 14 Feb. 2019 Accepted: 11 Dec. 2019 Published: 12 Mar. 2020

How to cite this article: Ng, K.H., Wang, C., Yap, J.B.H. Wood, L.C., \& Krisnan, S. (2020). Project Management Body of Knowledge for motion picture production in a fast-developing economy. South African Journal of Business Management, 51(1), a1458. https://doi.org/ 10.4102/sajbm.v51i1.1458

Read online:

Scan this QR code with your smart phone or mobile device to read online.

Purpose: Problems identified in the motion picture production include quality aspect, industry networking, marketing and promotion, and domestic focus of creative development work.

Design/methodology/approach: This article aims to develop a structured project management strategy to improve the Malaysian motion picture production.

Findings/results: Through the combination of a questionnaire survey and an interview survey, this research determined current barriers related to 10 knowledge areas of Project Management Body of Knowledge (PMBOK) in motion picture production projects.

Practical implications: This research developed a working model using the 10 knowledge areas in PMBOK for both the production and marketing projects in the motion picture industry in this fasting developing economy.

Originality/value: The 10 knowledge areas in PMBOK are consistent and valuable in making the film making processes sufficient. The motion picture production project management model developed in this study is experimental yet gives a fundamental understanding on strategy to focus and to conduct a proper film making or motion picture production.

Keywords: motion picture production; Project Management Body of Knowledge; film production; movie producing; marketing.

\section{Introduction}

Movies are visual experiences, and the motion picture's rhythmic and time-based structure makes film photography a very diverse and versatile sort of visual art compared to painting and photography (Burguer-Helmchen, 2012). Motion picture production could impact companies in the line of production, post-production, casting, crewing, equipment hiring, set design and property supply (Hashim, Ram, \& Tang, 2018) Along the way, it creates jobs in the hospitality-related industries like hotel businesses, caterings, restaurants and transportation, other than the motion picture industry itself (Singh \& Goyal, 2018). A growing motion picture industry reflects positively in aspects of tax revenue, economic growth and unemployment rate, and most governments are aware of this (Delre, Panico, \& Wierenga, 2017). Motion picture production is also a risky business venture as it involves great funding to begin with, but if the film or commercial flops, very little expenses can be recovered. According to Finney (2008), there is a gap between what is supposed to happen and what always happens in managing motion picture production projects. The irony of managing projects in the motion picture industry is not only to master the principles of how to manage film-making projects, but also to learn to cope with failures of these very principles to be effective (Fu, Yan, \& Feng 2018).

Hollywood has established that their 'project management' in film-making is no accident as they have handled billion-dollar worth of movies. Massive amount of knowledge about the creative business allows Hollywood to know how to or at least attempt to manage them (Finney, 2008). The Hollywood production system is adapted by various film industries globally (Persse, 2008). The implementation method and the end result gained from that are what that matter most. Managing motion picture production projects using methodology in Project Management Body of Knowledge (PMBOK) could increase the chances of completing projects on time, within budget and fulfilling stakeholders' satisfaction (Josler \& Burger, 2005).

Project Management Body of Knowledge could help a project to: (1) define and control project scope, (2) communicate among project participants, (3) project resource requirements, (4) identify Copyright: (C 2020. The Authors. Licensee: AOSIS. This work is licensed under the Creative Commons Attribution License. 
and communicate problem areas, (5) assess and mitigate project risk events and (6) align with organisational goals (Milosevic \& Patanakul, 2005).

The main challenges faced by the motion picture industries globally are competition and uncertainty (Hartungi, 2006). Competition is claimed to undesirably affect film industries in developing countries. Studies found that an increase in competition affects the competitiveness of the film industries in the less developed countries as they are unable to compete with international filmmakers and their industries (Hew, 2002; Stiglitz, 2002). Production houses in the motion picture industry strive in an external environment with noticeably greater uncertainties and changes (De Vany, 2011). Creativity is an advantage that helps organisations adapt in a changing environment (Wernerfelt \& Karnani, 1987). Creativity is neither replaceable nor imitable, and provides a source of sustainable benefit for those organisations that possess it (Barney, 1991; Mahoney \& Pandian, 1992). Studies have shown that individual careers in the creative industries are built by agents (gatekeepers of talent), critics (makers of image) (Giuffre, 1999; Kapsis, 1989) and commercial distributors of creative work (Zuckerman et al., 2003). Geographic location is one attractive factor for creative workers when facing numerous influences whether to rejuvenate themselves or to remain relevant to prospective jobs. The vague and elusive nature of these industries requires different marketing strategies, different from the common industrial marketing tactics. The marketplace needs to be redefined because the web of networks and institutions that produce the milieu in which organisations work in evolve and change. Problems identified in the Malaysian motion picture production are quality aspect, industry networking, marketing and promotion and domestic focus of creative development work (Rosnan \& Aziz, 2012), which were used in a matrix towards the end of this research. This article aims to develop a structured project management strategy to improve the Malaysian motion picture production. This research was specifically conducted to determine current barriers related to 10 knowledge areas of PMBOK, identify success factors and develop a project management framework for the Malaysian motion picture production. This research developed a working model using the 10 knowledge areas in PMBOK for both the production and marketing projects in the Malaysian motion picture industry.

\section{Project management in motion picture production \\ Success measurement on motion picture production projects}

A motion picture production project's success can be determined by two measures including the critical and the commercial success (Reid, 2000). Critical success measures depend on reviews, awards and festival exposures. On the contrary, the commercial success is mainly measured by box office revenue (Vogel, 2001), which can be translated as movie sales (business) and reviews of viewers (art) for a particular film (Jowett \& Linton, 1980). The dual nature of these success measures seems to reaffirm a belief that motion picture production is both 'business' and 'art' (Holbrook, 1999; Reid,
2000; Wyatt, 1994). According to Rossiter (2003), 'success' is measured by financial measures such as return on assets (ROA), return on investment (ROI), profit, box office gross, box office rentals and length of run. 'Artistic' or 'cultural' measures of success include reviews and awards that have frequently been adopted in academic models as prospective determinants of success rather than determining success measures on their own (Dominick, 1987; Sochay, 1994; Wyatt, 1994).

According to Rossiter (2003), a film project's success is also measurable using variables such as development speed, cycle-time reduction, profitability of other products like sequels, company branding, new ventures and product's technical success. Most movies are not financially successful and only few succeed (De Vany, 2011).

On an average seven out of 10 films are failures and suffer losses, only two of them achieve a breakeven. Thus, only one out of 10 movies is a success (Vogel, 2001). A successful movie usually collects a minimum of $373 \%$ returns from its investment. There are three main criteria to determine a film project's success: critical acclaim, financial performance and movie awards (Simonton, 2004). Other than these, there are a few more factors that contribute towards the success of a motion picture production project which are further discussed.

\section{Creativity}

Creativity is one of the possible sources of organisational effectiveness (Woodman, Sawyer, \& Griffin, 1993) and also forms part of an organisation's competitive advantage (Leonard \& Straus, 1997) in the economy that moves towards an informational, knowledge and symbolic form of production. Creativity in the workplace is largely affected by work environment and context (Banks \& Deuze, 2009). The entertainment providers have to be creative to distribute their products and services for audiences around the globe. The US Entertainment per say is one of the global leaders in financing, producing and distributing entertainment content. As a result, entertainment products have their 'shelf life' designed to include theatrical release, home entertainment, Video on Demand, Pay per View, Pay TV, Network TV, Cable TV and other markets both at the domestic and international levels (Cherbo, Vogel, \& Wyszomirski 2008).

\section{Showcase proficiencies}

Firms in the industry that are showcase proficient in the context of information, expertise and experience have a competitive advantage. The showcase proficiencies of filmmaking related firms facilitate learning in uncertain, changing and unpredictable situations (Miller \& Shamsie, 1996).

\section{Capabilities}

Motion picture projects require capabilities, such as knowledge, skill and experience, which replicate the types of knowledge-based resources that are useful when facing an uncertain, changing and unpredictable environment (Miller \& Shamsie, 1996). These intangible resources are important for organisations as they bring about innovation, creativity, 
flexibility and responsiveness - qualities that are close to the cultural and creative industries ( $\mathrm{O}^{\prime}$ Connor, 2007).

\section{Strategic partnership}

Co-production and international joint ventures are some of the forms of strategic partnership that have taken place. The partnerships allow filming activities to take place in many countries, which are parts of filming creative resources. This suggests that motion picture production does not take place within a cluster and/or a national context, but it has become a joint effort among producers from various countries (Morawetz, Hardy, Haslam, \& Randle, 2007).

\section{Information and communication technology}

The advancement in digital technology and communication has a direct effect on the motion picture industry, especially on enhancing how they work (Hall, 2018). These have created challenges for the motion picture industry in developing countries to catch up when they are lacking in advanced technology for film-making (Hashim et al., 2018).

\section{Teamwork}

Film-making is a collaborative work among crewmembers in which teamwork is key to success. A leader (director) leads the project in a coherent manner rather than through a scramble of individual gestures (Ferriani, Corrado, \& Boschetti, 2005). A good working relationship is acknowledged as the most important factor for crewmembers to work with each other (Blair, Grey, \& Randle, 2001). The film-related bodies should play a part in encouraging the motion picture industry. The chairman of 'Perbadanan Kemajuan Filem National Malaysia' (FINAS) emphasised the importance of cultivation and recognition of creativity, expertise and knowledge of young independent filmmakers (Ferriani et al., 2005).

\section{Communication}

During the motion picture production, meeting and working with a wide range of people from all backgrounds are inevitable (Perumal \& Woods, 2007). The motion picture industry has been reflected as an approach of communication and cultural expression set by the economic and social structures. A free and open communication among the group members is very important for a project. In a motion picture production, group members including the editor, cinematographer, production designer and composer are to fully comprehend the idea of the director, which is only possible through good communication and avoiding misunderstanding (Ferriani et al., 2005). Information sharing, collaboration and communication of implicit knowledge are identified as critical parts of the socialisation procedure, and have a high impact on crewmembers' performance (Marwick, 2001).

\section{Knowledge diversity}

The motion picture industry comprises academic and learned persons with good academic reputation like authors, directors, creative people and technical people. A combination of academic, artistic and technical groups of people forms a challenging yet interesting environment. Arguments arise over different issues, agreements and disagreements, human interaction with one other, knowledge sharing and exchange of opinions and views in diverse ways (Perumal \& Woods, 2007).

\section{Commitment}

Apart from knowledge and communication, commitment is one important factor when examining the relationship among members and organisations (Mowday, Porter, \& Steers, 1982). According to Meyer and Allen (1984), commitment is a social state or behavioural quality of being dedicated to a cause to attain benefits valued by others. Findings showed that projects with committed members achieve better results in contrast with those projects with less committed members (Bentein, Vandenberghe, Vandenberg, \& Stinglhamber, 2005). According to $\mathrm{Fu}$, Bolander and Jones (2009), organisational commitments are important for jobs that are more complex in nature and need flexibility.

\section{Motion picture production as a project}

According to Finney (2008), project management is a central pillar within the film business and each film is a project in itself. In addition, Ferriani et al. (2005) suggested that the activities of a film project occur in phases and are typically structured around interrelated sub-tasks, each of which requires the coordinated action and mutual adjustment of a subset of highly specialised skill-holders who provide their expertise at a critical time or in a critical combination. Filmmaking is a collaborative affair that requires attention to the coherency of a work; thus, a single coordinating sensibility must take the helm (Ferriani et al., 2005).

DeFillippi and Arthur (1998) described that for a production company to make a film, it is a single project that requires vision, strategy and a pre-approved budget. Similarly, project management in the motion picture industry is not so much about controlling the magical and creative elements of filmmaking, rather it is about managing the business aspects (Persse, 2008). Films share similar characteristics of a project; a film is made to gain profit in return and it is supported by project description. Similarly, a project involves activities with money to be spent, expecting results in return (Gittinger, 1982). Finney (2008) found that the motion picture industry is a highly challenging environment for it requires management of the creative process, the talent and a large amount of money, to ensure returns on investment.

Project management methodologies (PMMs) have been popularised in various industries for over 30 years.

Implementing a suitable project management methodology is strongly believed to be able to increase the chances of completing or finishing projects on time as per schedule, within the estimated budget and deliver the product to fulfil stakeholders' satisfaction upon requirement. There are few PMMs, such as PMBOK, managing the implementation for total projects (MITPs), administrative information system (AIS), Bates project management methodology (BPMM), customer ownership 
system teamwork (COST) and initiation, diagnostics, establishing, action, learning (IDEAL) (Axelos, 2017).

Project Management Body of Knowledge offers a general guide to manage most projects, thus it is comprehensive and flexible enough to be adapted by specialised projects (Conchúir, 2010). The method used by PMBOK is well matched with Software Engineering Institute's capability maturity model integration (CMMI) and ISO 9000. The five processes such as initiating, planning, executing, monitoring and controlling, and closing in PMBOK and 10 knowledge areas within it are interrelated throughout a project (Conchúir, 2010). The PMBOK knowledge area consists of integration management, scope management, time management, quality management, human resource management, communications management, risk management, procurement management and stakeholder management. Persse (2008) compared the standard PMBOK lifecycle with the Hollywood production system and found that both lifecycles are similar as they are offering the same functions throughout the lifecycle with the exception of the numbers of phases in both lifecycles.

During the development phase in a Hollywood production system and PMBOK's initiation phase, potential projects are identified, together with assessment of initial scopes to make a move based on decisions (Conchúir, 2010). At the pre-production phase of a Hollywood production system and PMBOK's planning phase, project plans, schedules and budgets are developed, staff members are assigned accordingly and project requirements are shared and analysed. During the production phase in a Hollywood production system and PMBOK's execution phase, activities in product development take place (Persse, 2008). Consequently, controlling, monitoring and adjustment activities against the plan are carried out in the postproduction phase. At the distribution phase of the Hollywood production system and PMBOK's closure phase, the product is packed and delivered to the end users or customers. Project management methodologies could help an organisation to manage projects within the guidelines, policies, procedures, rules and directives of the organisation, and PMBOK is a suitable guide (Zdanytė \& Neverauskas, 2011).

\section{Motion picture production in Malaysia}

In Malaysia, the motion picture industry is one of the fastest growing sectors in the economy, averaging at $11 \%$ per annum over the last 5 years. A baseline study on figures from the advertising, television and films, radio, animation, games, music, interactive software and new media segments, by Multimedia Super Corridor (MSC) Malaysia motion picture industry, has found that the creative content industry is reported to have an estimated worth of RM16 billion (Rosnan \& Aziz, 2012).

The Malaysian government has invested in the infrastructure, support services, funding, scholarships, global market access and policies, preparing to capture a significant share of the estimated USD 470 billion Asia-Pacific market. These include some of the Malaysian government's efforts and strategies to achieve this goal (Hoo, 2006). The strategies are (1) 30\% rebate as incentives offered by the government for movie producers shooting their movies in Malaysia; (2) policies of various agencies such as Malaysian Film Development Corporation Malaysia (FINAS) and Multimedia Development Corporation (MDeC) should push the creative content industry forward; (3) new platforms for traditionally produced content could be pay-per-view online downloads through the Internet and (4) grants awarded are managed wisely and efficiently, thus giving more monetary mileage to the developer, in return ensuring that the best possible work is produced. For instance, the Malaysia Animation Creative Content Centre (MAC3) laboratory in Cyberjaya, the multimillion ringgit centre, was created to provide resources for content developers in terms of technology, talent and even funding, so it should naturally go hand-in-hand with any new creative content initiatives.

The Malaysian motion picture industry is facing a few challenges in the project management context relating to scope management, risk management, cost management, human resource management and quality management. From the scope management aspect, the Malaysian motion picture industry is challenged by a smaller domestic market and smaller amount of films being produced. It was estimated that the total audience for feature films was approximately 5.29 million in 2008 out of a total population of approximately 28 million (Rosnan \& Aziz, 2012). Currently, annual productions of local drama and serials total to about 300-400 programmes, not including the in-house production by individual television stations and an average of 30 feature films (Rosnan \& Aziz, 2012).

From the risk-management context, high competition from foreign products in the domestic market has been identified as a greater challenge. Malaysia has no restriction on the import of foreign films; they are free to enter the local market with minimal requirements (Rosnan \& Aziz, 2012): (1) it has to pass through the Malaysian Film Censorship Board, which is the government authority that is responsible for granting licences to the film for public viewing, and (2) to provide subtitles in the Malay language. The local motion picture industry is affected by foreign products that undermine the local films in the local market. The motion picture industry is striving to compete with foreign films in the local market (Rosnan \& Aziz, 2012).

In terms of cost management, the Malaysian motion picture industry produces low-budget films. It will be tougher for the industry to compete in the international arena. It is especially difficult for local films to compete with big-budgeted foreign films (Rosnan \& Aziz, 2012). Human resource management is a challenge when there is insufficient talent in the motion picture industry because of shortage of quality graduates churned out by institutions of higher learning. They lack appropriate practical knowledge in motion picture production.

Malaysia is lagging behind countries like Singapore, Korea and Philippines which have conducive motion picture environments and enough talent to become creative hubs in 
the ASEAN region. Thus, the Malaysian government should generate strategies to attract foreign film projects to Malaysia to benefit from knowledge transfer and other externalities related to foreign operations in the host country. Film products are not only important as a means of cultural preservation, but films are now traded as commodities (Rosnan \& Aziz, 2012). In terms of quality management, the local films do not seem to attract enough audiences in most cases. The new Malaysian cinematic scene needs young filmmakers to explore new themes and content (Hoo, 2006).

\section{Research methods and procedures}

A questionnaire survey followed by a semi-structured interview survey was used in this study, as shown in Figure 1. There were 2000 questionnaire forms sent and 207 respondents participated as the expert group, including $26 \%$ directors, $22 \%$ producers, $18 \%$ writers, $14 \%$ technicians, $12 \%$ actors and $8 \%$ audients. Directors and producers play major roles in a film project from the development stage (initialisation) to the release stage (delivery or closure). The remaining groups' involvement was only during certain stages, for example, writers' involvement was during the pre-production stage, while actors' involvement was during the production stage. There were $64 \%$ respondents who had more than 5 years of experience in motion picture production, $32 \%$ had $4-5$ years of experience and $14 \%$ had 1-3 years of experience. In terms of the number of motion picture projects involved, $38 \%$ participated in more than 10 film projects, $32 \%$ participated in 6-10 film projects, $26 \%$ participated in 2-5 film projects and the rest participated in at least one film project. Basically, most of the respondents (about 70\%) have worked in more than five film projects, and more than $80 \%$ had more than 4 years of experience in the motion picture industry, which greatly increased the data sufficiency and research reliability and validity. Targeted film directors and producers based on a few selected films were invited to participate in the latter interviews, including the director of Istanbul Aku Datang film Bernard Chauly, local Tamil film director K.K Khanna and Indian Film director Dharanidharan. Figure 2 shows the film directors' scope and scale of the motion picture production target. The semi-structured interviews consisted of the following sections: (1) the film making process,

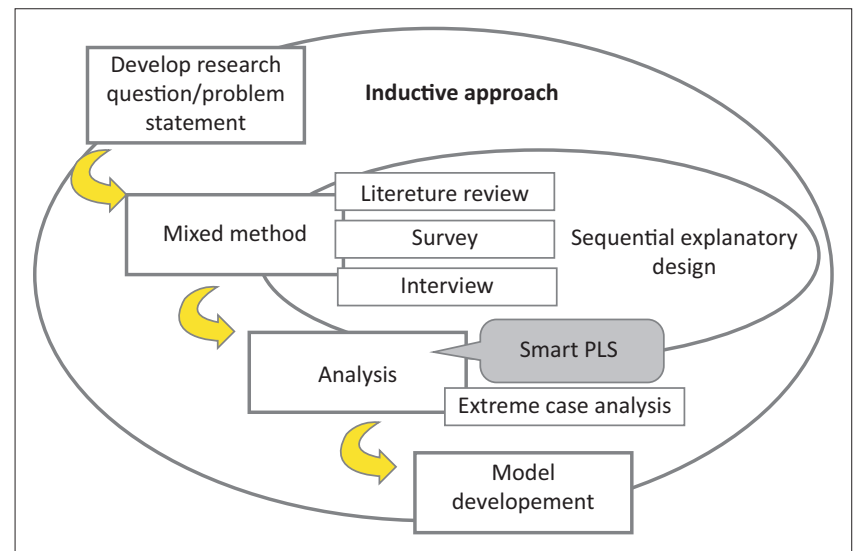

FIGURE 1: Flow of research methods and procedures.
(2) project management, (3) project issues, (4) project outcomes and (5) suggestions for improvement.

Each interview lasted for $2 \mathrm{~h}$, before which a draft of questions was sent over to the directors to confirm on data clarity. Follow-ups were made through email, which was found to be easy and time-saving. The interview questions for film directors were developed based on the 10 knowledge areas in PMBOK such as project integration management, project scope management, project time management, project cost management, project quality management, project human resource management, project communications management, project risk management, project procurement management and project stakeholder management. The questions looked into filmmakers' work on 'how' they managed their previous film projects in the project management perspective. Findings from both the questionnaire survey and the interview survey were used to illustrate a new motion picture production strategy model in an exploratory and experimental manner.

\section{Data analysis and interpretation}

The film itself is a project, thus a proper strategy is needed to develop a project. It is important to identify local filmmakers' level of understanding of project management and methodology. Figure 4 shows the probability of filmmakers knowing the project management methodology. There were $84 \%$ respondents familiar with the project management methodology, but only half of them (42\%) stated that they had implemented the project management methodology in their projects. The remaining 16\% respondents stated that they never heard about the project management methodology before. To further rectify their understanding of the project management methodology, the level of familiarity was tested via 10 knowledge areas in PMBOK. Figure 3 shows filmmakers' familiarity with PMBOK knowledge areas.

Among the 10 knowledge areas as stated in the chart, time management $(88 \%)$ and cost management $(66 \%)$ were known by most of the respondents, while the rest were not well known. This observation indicated that local filmmakers either knew about project management knowledge areas in a detailed manner (knowing without knowing it) or were not really familiar with that particular area. It clearly revealed that 10 knowledge areas of PMBOK need more involvement from researchers and film agencies to explore.

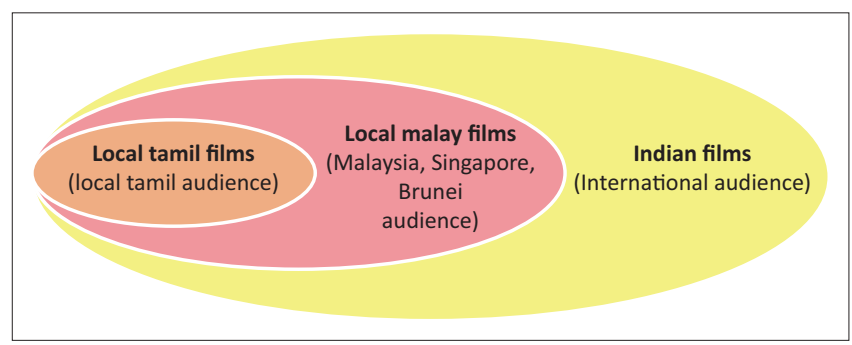

FIGURE 2: Comparison of motion picture production scale and target in Malaysia. 


\section{Partial least squares analysis using smart partial least squares}

A few dependent variables with possible influences towards other factors were identified. The relationship between the level of production, the rate of local production and genre popularity was developed using Smart PLS. Figure 4 shows the partial least squares path modelling estimation for the relationship among level of local motion picture production, the rate of local motion picture production and film genre popularity, with the following preliminary observations.

\section{Explanation of target endogenous variable variance}

The coefficient of determination $R^{2}$ at 0.301 for the genre popularity endogenous latent variable indicated that the two latent variables (level of production and rate of local production) weakly explained $30.1 \%$ of the variance genre popularity. According to Ringle et al. (2005), in marketing

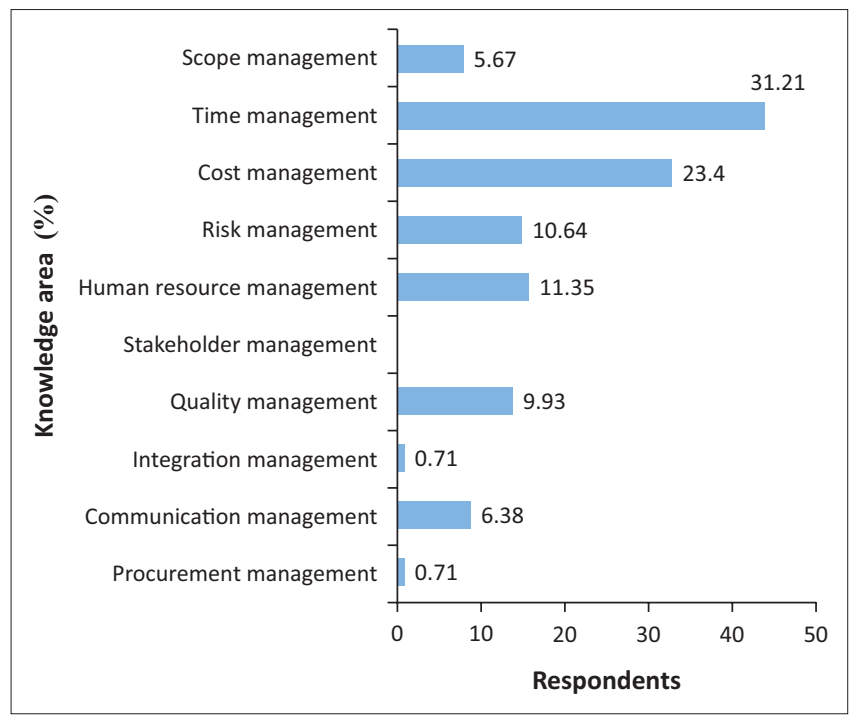

FIGURE 3: Familiarity of project management knowledge areas. research, $R^{2}$ value of 0.75 is substantial, 0.50 is moderate and 0.25 is weak. The level of production explained $34.8 \%$ of the variance of rate of local production.

\section{Inner model path coefficient sizes and significance}

The inner model suggested that rate of local production had the strongest effect on genre popularity (0.364), followed by level of production (0.249), which identified that the hypothesised path relationship between level of production and genre popularity, and rate of local production and genre popularity were statistically significant. Therefore, level of production and rate of local production were both moderately strong predictors of genre popularity.

\section{Outer model loadings}

Table 1 shows the outer loading reading for all the variables, where all $T$-statistics values were larger than 1.96 , so that the outer model loadings were highly significant according to Ringle et al. (2005).

TABLE 1: Outer model loadings.

\begin{tabular}{lccc}
\hline Variable & $\begin{array}{l}\text { Genre } \\
\text { popularity }\end{array}$ & $\begin{array}{l}\text { Level of } \\
\text { production }\end{array}$ & $\begin{array}{l}\text { Rate of local } \\
\text { production }\end{array}$ \\
\hline Cost & - & 15.437964 & - \\
Creativity & - & 55.488494 & - \\
Marketing & - & 13.735684 & - \\
Quality & - & 35.207940 & - \\
Technical & - & 28.024754 & - \\
Like_Action & 14.273983 & - & - \\
Like_Comedy & 21.687685 & - & - \\
Like_Drama & 21.323122 & - & - \\
Like_Horror & 10.627105 & - & - \\
Like_Love & 33.965412 & - & - \\
Rate_Action & - & - & 26.705767 \\
Rate_Comedy & - & - & 28.307590 \\
Rate_Drama & - & - & 18.128496 \\
Rate_Horror & - & - & 42.057235 \\
Rate_Love & - & - &
\end{tabular}

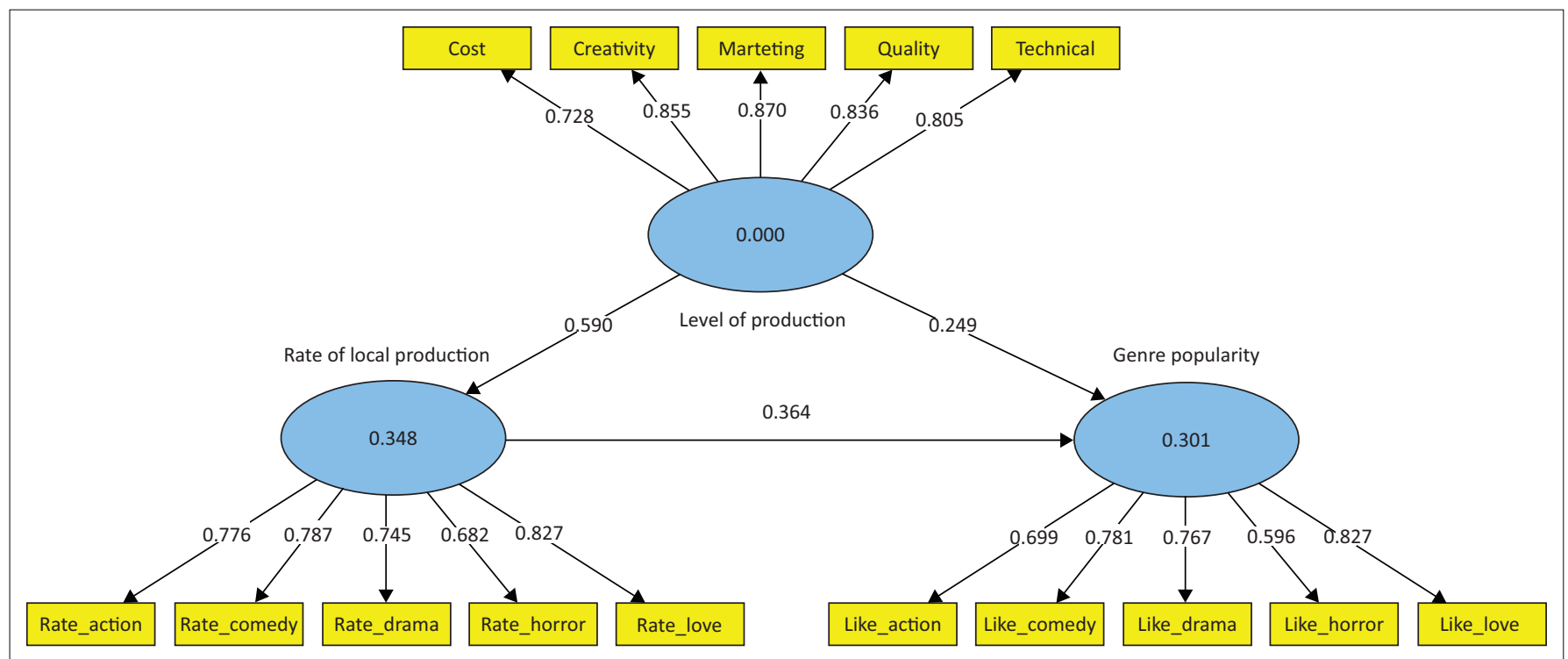

FIGURE 4: Partial least squares path modelling estimation among levels of local motion picture production, rate of local motion picture production and film genre popularity. 


\section{Indicator reliability}

It was essential to establish the reliability and validity of the latent variables to complete the examination of the structural model. Table 2 shows the results summary for reflective outer models on loadings, indicator reliability, composite reliability and average variance extracted (AVE) readings, where all indicators had individual indicator

TABLE 2: Results summary for reflective outer models.

\begin{tabular}{|c|c|c|c|c|c|}
\hline $\begin{array}{l}\text { Latent } \\
\text { variable }\end{array}$ & Indicators & Loadings & $\begin{array}{l}\text { Indicator reliability } \\
\text { (i.e., loadings) }\end{array}$ & $\begin{array}{l}\text { Composite } \\
\text { reliability }\end{array}$ & AVE \\
\hline \multirow{6}{*}{$\begin{array}{l}\text { Level of } \\
\text { production }\end{array}$} & - & - & - & 0.8555 & 0.6112 \\
\hline & Cost & 0.72781 & 0.5297 & - & - \\
\hline & Creativity & 0.85524 & 0.7314 & - & - \\
\hline & Marketing & 0.66965 & 0.4484 & - & - \\
\hline & Quality & 0.83603 & 0.6990 & - & - \\
\hline & Technical & 0.80463 & 0.6474 & - & - \\
\hline \multirow{6}{*}{$\begin{array}{l}\text { Genre } \\
\text { popularity }\end{array}$} & - & - & - & 0.8863 & 0.5452 \\
\hline & Like_Action & 0.69893 & 0.4885 & - & - \\
\hline & Like_Comedy & 0.78083 & 0.6097 & - & - \\
\hline & Like_Drama & 0.76655 & 0.5876 & - & - \\
\hline & Like_Horror & 0.59620 & 0.3555 & - & - \\
\hline & Like_Love & 0.82740 & 0.6849 & - & - \\
\hline \multirow{6}{*}{$\begin{array}{l}\text { Rate of local } \\
\text { production }\end{array}$} & - & - & - & 0.8753 & 0.5849 \\
\hline & Rate_Action & 0.77632 & 0.6027 & - & - \\
\hline & Rate_Comedy & 0.78676 & 0.6190 & - & - \\
\hline & Rate_Drama & 0.74485 & 0.5548 & - & - \\
\hline & Rate_Horror & 0.68183 & 0.4649 & - & - \\
\hline & Rate_Love & 0.82661 & 0.6833 & - & - \\
\hline
\end{tabular}

AVE, average variance extracted.

TABLE 3: The Fornell-Larcker criterion analysis for checking discriminant validity.

\begin{tabular}{lccc}
\hline Variable & $\begin{array}{c}\text { Genre } \\
\text { popularity }\end{array}$ & $\begin{array}{c}\text { Level of } \\
\text { production }\end{array}$ & $\begin{array}{c}\text { Rate of local } \\
\text { production }\end{array}$ \\
\hline Genre popularity & 1.000000 & - & - \\
Level of production & 0.463750 & 1.000000 & - \\
Rate of local production & 0.510628 & 0.590003 & 1.000000 \\
\hline
\end{tabular}

TABLE 4: $T$-statistics of path coefficients and outer loadings.

\begin{tabular}{|c|c|c|c|c|}
\hline Model items & $\begin{array}{l}\text { Level of } \\
\text { production }\end{array}$ & $\begin{array}{c}\text { Genre } \\
\text { popularity }\end{array}$ & $\begin{array}{l}\text { Rate of local } \\
\text { production }\end{array}$ & $T$-statistics \\
\hline \multicolumn{5}{|l|}{ Inner model items } \\
\hline $\begin{array}{l}\text { Level of production -> } \\
\text { genre popularity }\end{array}$ & - & - & - & 3.5955 \\
\hline $\begin{array}{l}\text { Level of production -> } \\
\text { rate of local production }\end{array}$ & - & - & - & 14.2192 \\
\hline $\begin{array}{l}\text { Rate of local production -> } \\
\text { genre popularity }\end{array}$ & - & - & - & 4.3085 \\
\hline \multicolumn{5}{|l|}{ Outer model items } \\
\hline Cost & 16.249072 & - & - & - \\
\hline Creativity & 59.345413 & - & - & - \\
\hline Marketing & 12.856471 & - & - & - \\
\hline Quality & 30.190058 & - & - & - \\
\hline Technical & 27.028184 & - & - & - \\
\hline Like_Action & - & 14.465527 & - & - \\
\hline Like_Comedy & - & 22.635165 & - & - \\
\hline Like_Drama & - & 21.091996 & - & - \\
\hline Like_Horror & - & 10.058649 & - & - \\
\hline Like_Love & - & 34.243277 & - & - \\
\hline Rate_Action & - & - & 25.147908 & - \\
\hline Rate_Comedy & - & - & 31.308015 & - \\
\hline Rate_Drama & - & - & 20.046708 & - \\
\hline Rate_Horror & - & - & 15.951040 & - \\
\hline Rate_Love & - & - & 45.934929 & - \\
\hline
\end{tabular}

reliability values that were much larger than the minimum acceptable level at 0.4 and most of them closed to the preferred level at 0.7 , except Like_Horror at 0.3555 which was under the minimum acceptable level. According to Hulland (1999), indicator reliability at 0.70 or higher is preferred, and if it is an exploratory research, 0.4 or higher is acceptable.

\section{Internal consistency reliability}

The composite values were larger than 0.6 and the high level of internal consistency reliability was demonstrated among all three reflective latent variables according to Bagozzi and Yi (1988).

\section{Convergent validity}

Each latent variable's AVE was evaluated to check convergent validity and all AVE values were greater than the acceptable threshold at 0.5 , so the convergent validity was confirmed according to Bagozzi and Yi (1988).

\section{Discriminant validity}

Fornell and Larcker (1981) recommended that the square root of AVE in each latent variable could be used to establish discriminant validity if this value was larger than other correlation values among the latent variables. Table 3 shows the Fornell-Larcker criterion analysis for checking the discrimination validity, and the latent variable for genre popularity, level of production and rate of local production were 1.0 each, which indicated that the discriminant validity was well established.

\section{Checking the structural path significance in bootstrapping}

Table 4 shows $T$-statistics of path coefficients for the inner model, where using a two-tailed $T$-test with a significance level at 5\%, the path coefficient was significant because the $T$-statistic values were larger than 1.96 according to Ringle et al. (2005). All the $T$-statistic values were larger than 1.96, thus all path coefficients in the inner model were statistically significant. Table 5 shows the $T$-statistic values of path coefficients for the outer model, where all the $T$-statistic values were also larger than 1.96 .

Table 5 summarises the observation level of acceptance to confirm the model reliability, where the perceived level of local

TABLE 5: Observation level of acceptance summary.

\begin{tabular}{ll}
\hline Observations & Observation acceptance level \\
\hline Target endogenous variable variance & Weak \\
Inner model path coefficient sizes and significance & Average \\
Outer model loadings & Good \\
Indicator reliability & Good \\
Internal consistency reliability & Good \\
Convergent validity & Good \\
Discriminant validity & Good \\
Structural path significance in bootstrapping: & Good \\
$T$-statistics of path coefficients (inner model) & \\
Structural path significance in bootstrapping: & Good \\
$T$-statistics of outer loadings & \\
\hline
\end{tabular}


motion picture production loading values of creativity, quality, technical, cost and marketing were $0.855,0.836,0.806,0.728$ and 0.670 , respectively. The level of production affects the rate of local production moderately. Ratings given to film genre affected the ratings of local motion picture production such as (by decreasing order) love, comedy, action, drama and horror with loadings at $0.872,0.787,0.776,0.745$ and 0.682 .

The genres of love, comedy and action played an important role in local film ratings, although they did not affect the ratings drastically as the influencing power was only 3.5 out of 10. Effects on local film genre popularity were influenced mostly by the ratings given to local production (0.364) compared to level of local production (0.249). Audience likability of genre affected the genre popularity though not that significantly, as audience craze for (decreasing order) love, comedy, drama, action and horror had loadings at $0.872,0.781$, $0.767,0.699$ and 0.596 , respectively. In summary, the level of production that fell to the level of creativity, quality and technical aspects gave high ratings to genres such as love, comedy, action and drama which in return resulted in high turnout of audience for new release of films belonging to genres such as love, comedy and drama. Although not significant, it still provided a momentum or created an impact. Figure 5 shows the relational summary of survey findings.

\section{Interview survey analysis}

The questionnaire survey analysis was further compared with the findings from the interview survey conducted on three film directors, including K.K.K., B.C.C. and D.D.T. K.K.K. and B.C.C. were local film directors, while D.D.T. was a film director from India who made Tamil films in Southern India. The scope of the selected filmmakers was varied, which definitely provided an advantage of comparing their knowledge and experience in filmmaking. K.K.K.'s films were more focused towards the local Tamil audience, while B.C.C.'s films catered to Malaysian, Singaporean and Brunei audiences. On the contrary, D.D.T.'s films focused on international Tamil audiences. Table 6 shows the output from the content analysis conducted through the coding process.

The questionnaire survey outcomes were tangible with the interview survey conducted with the directors. All the directors and their teams were using Microsoft Excel Sheets to manage the schedule and the budget of film projects. They were aware that Hollywood was using the Movie Magic software to manage time and cost, but they never had a chance to explore the Movie Magic software because of current practices. Director B.C.C.'s films have received positive review and feedback from the media, the audiences and belonged to the love genre. His projects were mostly a combination of both love genre and drama. According to B.C.C., local audience preferred the love genre, and he believed that these genres could give more fruitful outcomes compared to the rest and he was not in the line of directors and producers who were prone to the horror genre, though the Malaysian motion picture production trend had been inclined towards the horror genre during the past few years.

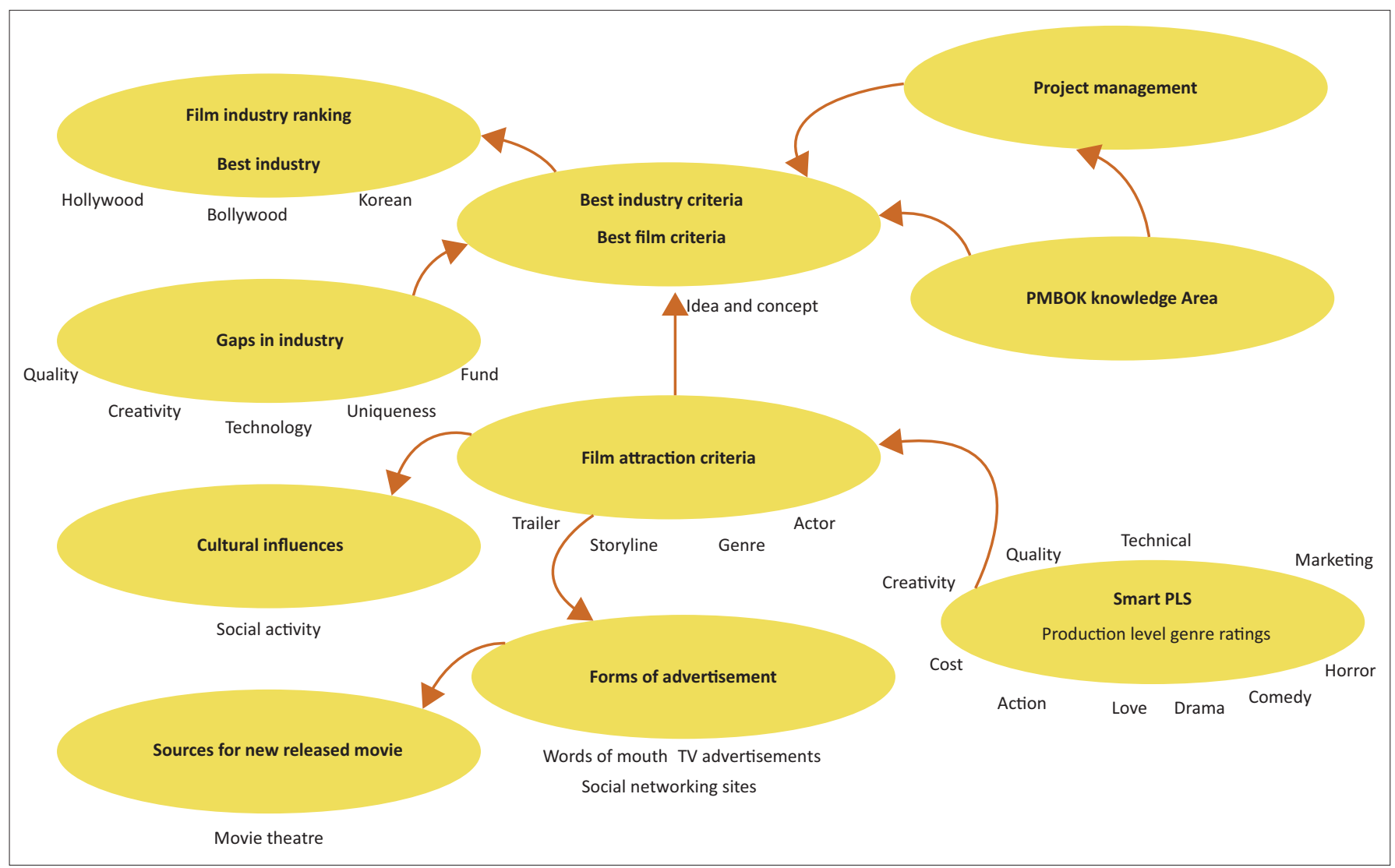

FIGURE 5: Relational summary of survey findings. 
TABLE 6: Content analysis on interview survey.

\begin{tabular}{|c|c|c|c|}
\hline Test Items & Scope & Current application & Best practices \\
\hline $\mathrm{T} 1$ & Delay/cost overrun detection method & - Microsoft Excel & $\begin{array}{l}\text { - Movie magic (Hollywood) } \\
\text { - PMBOK (Microsoft project) }\end{array}$ \\
\hline $\mathrm{T} 2$ & Genre selection & $\begin{array}{l}\text { - Based on targeted audience } \\
\text { - Love } \\
\text { - Action }\end{array}$ & - Study audience ratio and expectation (market analysis) \\
\hline \multirow[t]{2}{*}{ T4 } & $\begin{array}{l}\text { Benchmarking scheme (among film or } \\
\text { industry) }\end{array}$ & $\begin{array}{l}\text { - Quality } \\
\text { - Storyline }\end{array}$ & $\begin{array}{l}\text { - Quality } \\
\text { - Storyline }\end{array}$ \\
\hline & Quality assurance & $\begin{array}{l}\text { - Product success } \\
\text { - Satisfaction or reach expectation } \\
\text { - Box office } \\
\text { - Awards }\end{array}$ & $\begin{array}{l}\text { - During production: } \\
\text { * Progress close to expectation } \\
\text { - After production: } \\
\text { - Movie preview } \\
\text { - After release: } \\
\text { - Box office } \\
\text { - Awards }\end{array}$ \\
\hline T5 & Best practices & $\begin{array}{l}\text { - Hollywood production system or motion picture } \\
\text { production lifecycle } \\
\text { - Experience } \\
\text { - Everyone knows everything }\end{array}$ & $\begin{array}{l}\text { - PMBOK } \\
\text { - Hollywood production system } \\
\text { - Triple constraints }\end{array}$ \\
\hline T6 & Success factors & $\begin{array}{l}\text { - Surprise the audience } \\
\text { - New concept or approach } \\
\text { - Creativity }\end{array}$ & $\begin{array}{l}\text { - Cost management (PMBOK) } \\
\text { - Time management (PMBOK) } \\
\text { - Quality management (PMBOK) } \\
\text { - Scope management (PMBOK) }\end{array}$ \\
\hline T7 & Marketing strategy & $\begin{array}{l}\text { - Early as production stage } \\
\text { - Trailer } \\
\text { - Film festivals }\end{array}$ & $\begin{array}{l}\text { - Trailer } \\
\text { - Social media } \\
\text { - Film festivals } \\
\text { - Scope management (PMBOK) }\end{array}$ \\
\hline T8 & Risk identification and management & $\begin{array}{l}\text { - Spontaneous } \\
\text { - By experience }\end{array}$ & • Risk management (PMBOK) \\
\hline T9 & Cast \& crew engagement & $\begin{array}{l}\text { - Casting } \\
\text { - Contacts and past experience }\end{array}$ & - HR management (PMBOK) \\
\hline T10 & Work flow & $\begin{array}{l}\text { - Task oriented } \\
\text { - Role specification } \\
\text { - By experience }\end{array}$ & $\begin{array}{l}\text { - Work breakdown structure (WBS) } \\
\text { - Communication management (PMBOK) }\end{array}$ \\
\hline
\end{tabular}

PMBOK, Project Management Body of Knowledge; HR, human resources; WBS, Work breakdown structure.

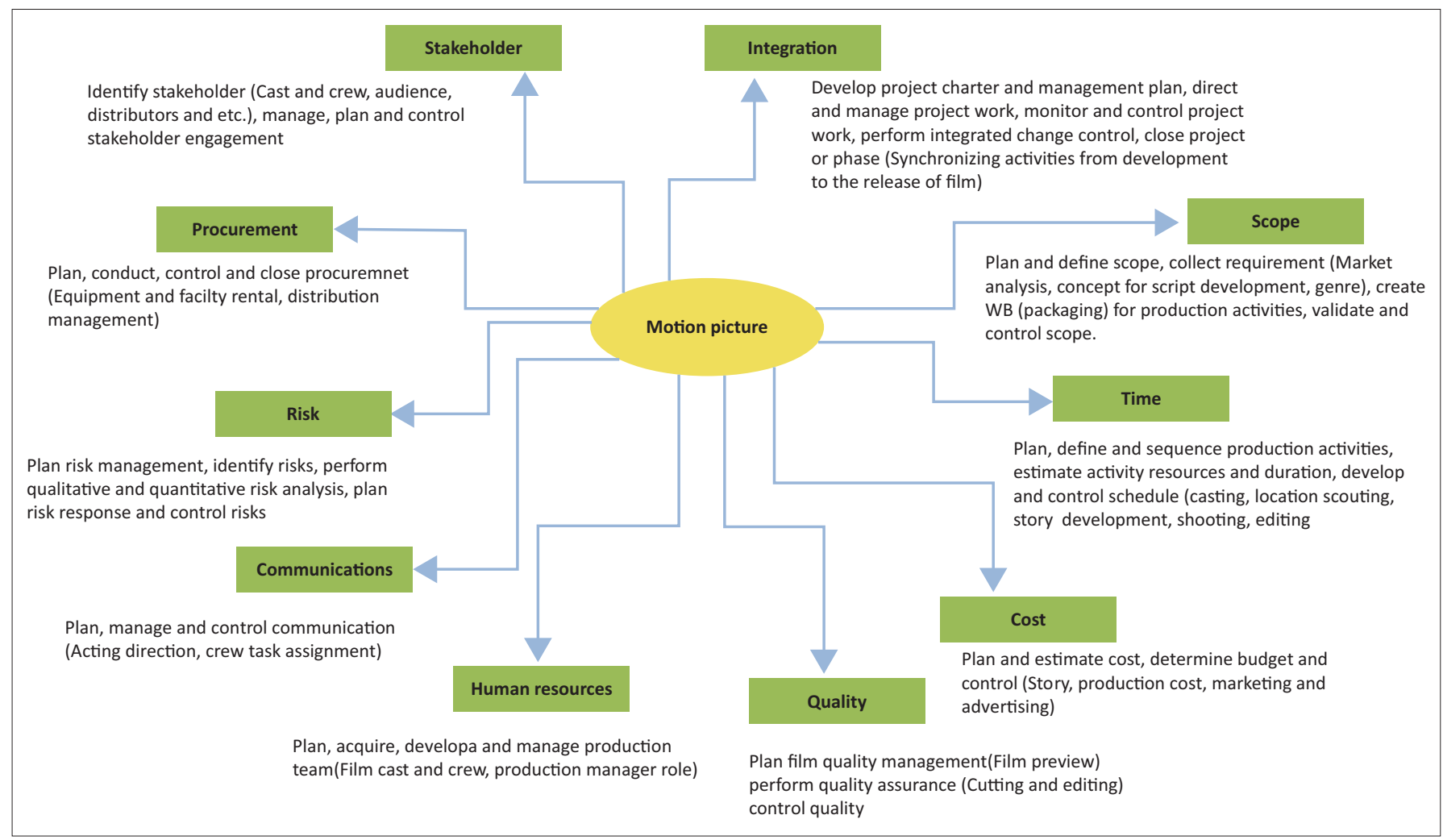

FIGURE 6: Motion picture production activities and 10 knowledge areas of Project Management Body of Knowledge.

According to B.C.C. and D.D.T., quality was the most important criteria that should be given a high priority to produce a successful film. While qualities were measured in three ways such as assuring progress close to expectation (during production), movie preview (after production) and box office or awards (after release), they also agreed that the genre selection was as important as knowing the target audience and their population, as it could lead to a good marketing strategy. Malaysia cashed on Korean Pop or K-Pop by following the Korean wave known as 'Hallyu'. 
B.C.C. believed that implementing 'Hallyu' in local films could attract more audience especially urban citizens. Surprisingly, catering to the audience with a new concept or approach through creativity was the main factor for a film's success and in project management, and it could be achieved through triple constraints consisting of cost management, time management and quality management. All the three directors admitted that they never implemented any project management tool or technique as per PMBOK and PRINCE2. They agreed that complying with PMBOK might be useful but only after practising through proper coaches and guidance by responsible bodies. Figure 6 shows the flexibility of motion picture production activities adopted within 10 knowledge areas in PMBOK.

\section{Motion picture production activities and 10 knowledge areas of Project Management Body of Knowledge}

Motion picture production and film success rely on effective project management, and PMBOK is not limited to time and cost management, but there are various knowledge areas to be incorporated into motion picture production, as shown in Figure 6. Market analysis and inspiration generation are fundamentals in initiating a film project, which are link to the scope management at the film development stage. Project Management Body of Knowledge areas such as project plan development, scope planning, schedule development, quality planning, cast and acquisition, communication planning, risk management planning and procurement planning are involved in the pre-production stage. At the production stage where shooting takes place, project plan execution, quality assurance, team development, information distribution and contract administration are to be conducted. During the postproduction stage, all knowledge areas in PMBOK are involved through editing and monitoring processes. The administrative closure and contract closure are within the distribution stage when a film is released. A motion picture production project management model is shown in Figure 7, which is experimental yet gives a fundamental understanding on the strategy to focus and to conduct a proper film making or motion picture production. It is necessary to study the audience's requirement to deliver a product as per their expectation. Once the genre is confirmed, the film project can be kicked off using the regular Hollywood motion picture production method which consists of development, pre-production, production, post-production and distribution processes. The uniqueness of this model is the integration of the Hollywood motion picture production method with the 10 knowledge areas of PMBOK.

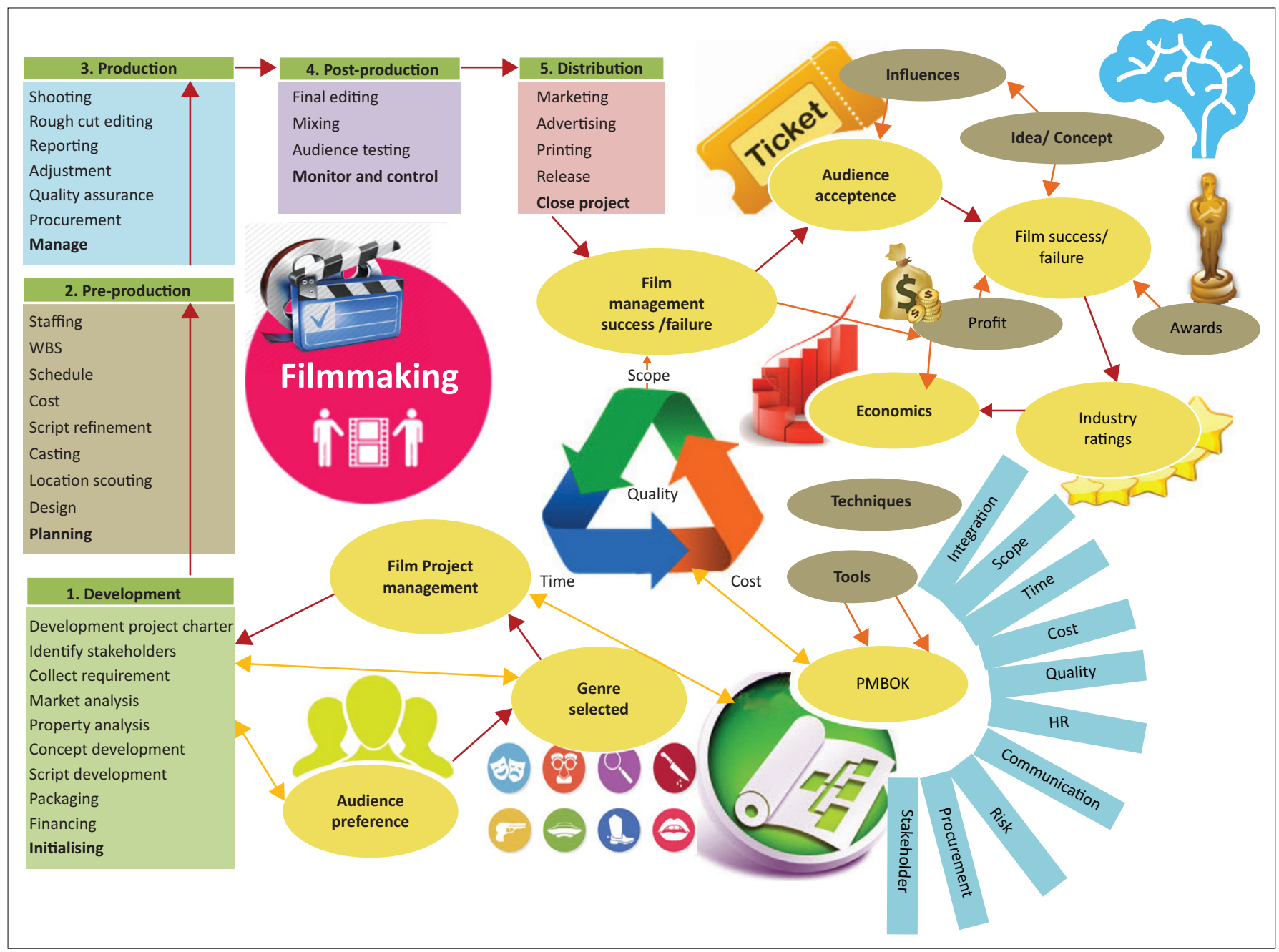

PMBOK, Project Management Body of Knowledge; HR, human resources.

FIGURE 7: The motion picture production project management model. 


\section{Conclusion}

The success of a motion picture production project relies on effective project management. Implementing PMBOK tools and techniques as a part of the film making methodology could increase the possibility of film management success and reduce the chances of failure. Project management tools and techniques such as Movie Magic and Microsoft Project for scheduling and budgeting, WBS for activity segregation, and critical path method (CPM) for time management earned value management for cost management and SWOT analysis for risk management could offer great assistance in motion picture production. Project Management Body of Knowledge areas could ensure that a motion picture production project is well managed within the project triple constraints such as time, cost and quality requirements. A film's success or failure depends on audience acceptance and criteria such as idea or concept, profit and awards. It is essential to study customers' requirement before kick-off of a project and to avoid unexpected losses during the project implementation. Audience expectations and requirements on the genre are needed to be analysed upfront before project development by surveying targeted population's demographical data such as age scale and educational status. Once a genre is confirmed, a film project could then be kicked off followed by phases such as development, pre-production, production, post-production, and distribution. The 10 knowledge areas in PMBOK are consistent and valuable in making the film making processes sufficient. The motion picture production project management model developed in this study is experimental yet gives a fundamental understanding on the strategy to focus and to conduct a proper film making or motion picture production. This study is limited to the motion picture industry within developing countries especially Malaysia. Similar studies can be conducted in other countries and regions for comparison purposes. In future research, case studies are recommended for the validation and implementation of the motion picture production project management model.

\section{Acknowledgements}

The authors are grateful to Huaqiao University for the financial support through research grant number (17BS201).

\section{Competing interests}

The authors declare that they have no financial or personal relationships that may have inappropriately influenced them in writing this article.

\section{Authors' contributions}

C.W. and K.H.N. conducted the research and compiled the first draft; J.B.H.Y. conducted the data analysis; and S.K. contributed to the conceptual development and the editing.

\section{Ethical consideration}

The authors declare that there is no ethical consideration required for this article and followed all ethical standards for carrying out research.

\section{Funding information}

The study was funded by the Huaqiao University through the research grant number (17BS201).

\section{Data availability statement}

All data, models, and code generated or used during the study appear in the published article.

\section{Disclaimer}

The views and opinions expressed in this article are those of the authors and do not necessarily reflect the official policy or position of any affiliated agency of the authors.

\section{References}

Axelos, A. (2017). Managing successful projects with PRINCE2. New York: TSO Publishing.

Bagozzi, R.P., \& Yi, Y. (1988). On the evaluation of structural equation models. Journal of The Academy of Marketing Science, 16(1), 74-94.

Banks, J., \& Deuze, M. (2009). Co-creative labour. International Journal of Cultural Studies, 12(5), 419-431. https://doi.org/10.1177/1367877909337862

Barney, J. (1991). Firm resources and sustained competitive advantage. Journal of Management, 17(1), 99-120. https://doi.org/10.1177/014920639101700108

Bentein, K., Vandenberghe, C., Vandenberg, R., \& Stinglhamber, F. (2005). The role of change in the relationship between commitment and turnover: A latent growth
modeling approach. Journal of Applied Psychology, $90(3), 468-472$. https://doi. org/10.1037/0021-9010.90.3.468

Blair, H., Grey, S., \& Randle, K. (2001). Working in film-Employment in a project based industry. Personnel Review, 30(2), 170-185. https://doi.org/10.1108/ 00483480110380334

Burguer-Helmchen, T. (2012). Entrepreneurship-creativity and innovative business models. London: IntechOpen Press.

Cherbo, J.M., Vogel, H.L., \& Wyszomirski, M.J. (2008). Understanding the arts and creative sector in the United States, Trenton, NJ: Rutgers University Press.

Conchúir, D.O. (2010). Overview of the $P M B O K^{\circledR}$ Guide: Short cuts for PMP® Certification. Berlin: Springer-Verlag.

De Vany, A. (2011). Hollywood economics: How extreme uncertainty shames the motion picture industry. London: Routledge.

Defillippi, R.J., \& Arthur, M.B. (1998). 15 paradox in project-based enterprise: The case of film making. California Management Review, 40(2), 189-191. https://doi. org/10.2307/41165936

Delre, S.A., Panico, C., \& Wierenga, B. (2017). Competitive strategies in the motion picture industry: An ABM to study investment decisions. International Journal of Research in Marketing, 34(1), 69-99. https://doi.org/10.1016/j.ijresmar. 2016.05.005

Dominick, J.R. (1987). Film economics and film content: 1963-1983. Current Research in Film: Audiences, Economics, and Law, 3, 136-162.

Ferriani, S., Corrado, R., \& Boschetti, C. (2005). Organizational learning under organizational impermanence: Collaborative ties in film project firms. Journal of Management and Governance, 9(3-4), 257-285. https://doi.org/10.1007/ s10997-005-7422-2

Finney, A. (2008). Learning from sharks: Lessons on managing projects in the independent motion picture industry. Long Range Planning, 41(1), 107-115. https://doi.org/10.1016/j.Irp.2007.11.002

Fornell, C., \& Larcker, D.F. (1981). Structural equation models with unobservable variables and measurement error: Algebra and statistics. Journal of Marketing Research, 1(1981), 382-388.

Fu, F.Q., Bolander, W., \& Jones, E. (2009). Managing the drivers of organizational commitment and salesperson effort: An application of Meyer and Allen's threecomponent model. The Journal of Marketing Theory and Practice, 17(4), 335-350. https://doi.org/10.2753/MTP1069-6679170403

Fu, S., Yan, Q., \& Feng, G.C. (2018). Who will attract you? Similarity effect among users on online purchase intention of movie tickets in the social shopping context. International Journal of Information Management, 40, 88-102. https://doi. org/10.1016/j.ijinfomgt.2018.01.013

Gittinger, J.P. (1982). Economic analysis of agricultural projects. Baltimore, MD: John Hopkins University Press. 
Giuffre, K. (1999). Sandpiles of opportunity: Success in the art world. Social Forces, 77(3), 815-832. https://doi.org/10.2307/3005962

Hall, D. (2018). Black Panther Motion Picture. The Journal of Social Studies Research, 42(4), 393-395. https://doi.org/10.1016/j.jssr.2018.06.004

Hartungi, R. (2006). Could developing countries take the benefit of globalisation International Journal of Social Economics, 33(11), 728-743. https://doi. org/10.1108/03068290610705652

Hashim, M.J., Ram, S., \& Tang, Z. (2018). Uncovering the effects of digital movie format availability on physical movie sales. Decision Support Systems, 117(February), 75-86. https://doi.org/10.1016/j.dss.2018.10.016

Hew, D. (2002). Rethinking the East Asian Miracle. ASEAN Economic Bulletin, 19(2), 217-218.

Holbrook, M.B. (1999). Popular appeal versus expert judgments of motion pictures. Journal of Consumer Research, 26(2), 144-155. https://doi.org/10.1086/209556

Hoo, G.W.L. (2006). Building a new Malaysian national cinema. Paper presented the Media: Policies, Cultures and Futures in the Asia Pacific Region Conference at Curtin University of Technology, 16-18 November 2006. Perth: Australia.

Hulland, J. (1999). Use of partial least squares (PLS) in strategic management research a review of four recent studies. Strategic Management Journal, 20(2), 195-204.

Josler, C., \& Burger, J. (2005). Project Management Methodology in Human Resource Management. Cupa HR Journal, 56(2), 25.

Jowett, G., \& Linton, J.M. (1980). Movies as mass communication (Vol. 4). Beverly Hills, CA: Sage. Beverly Hills.

Kapsis, R.E. (1989). Reputation building and the film art world. The Sociological Quarterly, 30(1), 15-35. https://doi.org/10.1111/j.1533-8525.1989.tb01509.x

Leonard, D. \& Straus, S. (1997). Putting your company's whole brain to work. Harvard Business Review, 75(1997), 110-122.

Mahoney, J.T., \& Pandian, J.R. (1992). The resource-based view within the conversation of strategic management. Strategic Management Journal, 13(5), 363-380. https://doi.org/10.1002/smj.4250130505

Marwick, A.D. (2001). Knowledge management technology. IBM Systems Journal, 40(4), 814-830. https://doi.org/10.1147/sj.404.0814

Meyer, J.P., Allen, \& N.J. (1984). Testing the 'side-bet theory' of organizational commitment: Some methodological considerations. Journal of Applied Psychology, 69(3), 372-373. https://doi.org/10.1037/0021-9010.69.3.372

Miller, D., \& Shamsie, J. (1996). The resource-based view of the firm in two environments: The Hollywood film studios from 1936 to 1965 . Academy of Management Journal, 39(3), 519-543. https://doi.org/10.2307/256654

Milosevic, D., \& Patanakul, P. (2005). Standardized project management may increase development projects success. International Journal of Project Management, 23(3), 181-192. https://doi.org/10.1016/j.ijproman.2004.11.002

Morawetz, N., Hardy, J., Haslam, C., \& Randle, K. (2007). Finance, policy and industrial dynamics: The rise of co-productions in the motion picture industry Industry and Innovation, 14(4), 421-443. https://doi.org/10.1080/13662710701524072
Mowday, R.T., Porter, L.W., \& Steers, R.M. (1982). Employee-organization linkages: The psychology of commitment, absenteeism, and turnover. New York: Academic Press.

O'Connor, J. (2007). The cultural and creative industries: A review of the literature. Creative Partnership Series. London: Art Council England.

Persse, J.R. (2008). Hollywood secrets of project management success. Redmond, WA Microsoft Press.

Perumal, V., \& Woods, P.C. (2007). The need for knowledge management in the Malaysian motion picture industry: A case study. Journal of Information and Knowledge Management, 6(3), 173-180. https://doi.org/10.1142/S021964920 7001731

Reid, M.A. (2000). Success factors in Australian cinema in the 1990s. Masters by Research thesis. Brisbane: Queensland University of Technology.

Ringle, C.M., Wende, S., \& Will, A. (2005). SmartPLS 2.0 (beta). Hamburg: SmartPLS Press.

Rosnan, H., \& Aziz, Z.D.A. (2012). Film business in Malaysia: challenges and opportunities. International Journal of Humanities and Social Science, 2(12), 198-202.

Rossiter, C. (2003). The factors that drive success in motion picture development: An Australian context. Masters by Research thesis. Brisbane: Queensland University of Technology.

Simonton, D.K. (2004). Group artistic creativity: Creative clusters and cinematic success in feature films. Journal of Applied Social Psychology, 34(7), 1494-1520. https://doi.org/10.1111/j.1559-1816.2004.tb02016.x

Singh, J., \& Goyal, G. (2018). Anticipating movie success through crowdsourced social media videos. Computers in Human Behavior, 101(December), 484-494. https:// doi.org/10.1016/j.chb.2018.08.050

Sochay, S. (1994). Predicting the performance of motion pictures. Journal of Media Economics, 7(4), 1-20. https://doi.org/10.1207/s15327736me0704_1

Stiglitz, J.E. (2002). Information and the change in the paradigm in economics. The American Economic Review, 92(3), 460-501. https://doi.org/10.1257/ 00028280260136363

Vogel, H.L. (2001). Entertainment industry economics: A guide for financial analysis. Cambridge: Cambridge University Press.

Wernerfelt, B., \& Karnani, A. (1987). Competitive strategy under uncertainty. Strategic Management Journal, 8(2), 187-194. https://doi.org/10.1002/smj.4250080209

Woodman, R.W., Sawyer, J.E., \& Griffin, R.W. (1993). Toward a theory of organizational creativity. Academy of Management Review, 18(2), 293-321. https://doi. org/10.5465/amr.1993.3997517

Wyatt, J. (1994). High concept: Movies and marketing in Hollywood. Austin, TX: University of Texas Press.

Zdanyte, K., \& Neverauskas, B. (2011). The Theoretical substation of project management challenges. Economics and Management, 16(2011), 1013-1014.

Zuckerman, E.W., Kim, T.-Y., Ukanwa, K., \& Rittman, V.J. (2003). Robust identities or

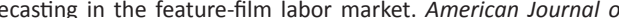
Sociology, 108(5), 1018-1074. 